\title{
The Effect of Treatment of Acidosis on Calcium Balance in Patients with Chronic Azotemic Renal Disease*
}

\author{
John R. Litzow, $†$ Jacob Lemann, JR., and Edward J. Lennon $\ddagger$ \\ (From the Department of Internal Medicine and the Clinical Research Center, Marquette \\ University School of Medicine, and the Milwaukee County General Hospital, \\ Milwaukee, Wisc.)
}

\begin{abstract}
Summary. Small but statistically significant negative calcium balances were found in each of eight studies in seven patients with chronic azotemic renal disease when stable metabolic acidosis was present. Only small quantities of calcium were excreted in the urine, but fecal calcium excretion equaled or exceeded dietary intake. Complete and continuous correction of acidosis by $\mathrm{NaHCO}_{3}$ therapy reduced both urinary and fecal calcium excretion and produced a daily calcium balance indistinguishable from zero.

Apparent acid retention was found throughout the studies during acidosis, despite no further reduction of the serum bicarbonate concentration. The negative calcium balances that accompanied acid retention support the suggestion that slow titration of alkaline bone salts provides an additional buffer reservoir in chronic metabolic acidosis. The treatment of metabolic acidosis prevented further calcium losses but did not induce net calcium retention. It is suggested that the normal homeostatic responses of the body to the alterations in ionized calcium and calcium distribution produced by raising the serum bicarbonate might paradoxically retard the repair of skeletal calcium deficits.
\end{abstract}

\section{Introduction}

Skeletal abnormalities may occur in the course of chronic azotemic renal disease. Osteomalacia, osteitis fibrosa, and osteosclerosis may be recognized by $\mathrm{X}$ ray, singly or in combination, and are found with greater frequency on histologic examination of bone (1-3). Chronic metabolic acidosis, acquired vitamin $\mathrm{D}$ resistance, and secondary hyperparathyroidism have each been con-

* Submitted for publication April 11, 1966; accepted October 31, 1966.

This investigation was supported in part by research grants RO1 AM 08924 and 5 MO1 FR-00058, both from the U. S. Public Health Service.

Presented in part before the Thirty-ninth Annual Meeting of the Central Society for Clinical Research, November 1966, Chicago, Ill.

$\dagger$ Trainee in the Dept. of Medicine, Marquette University School of Medicine, and supported by U. S. Public Health Service training grant 2 T1 AM5023 (e).

$\ddagger$ Address requests for reprints to Dr. Edward J. Lennon, Milwaukee County General Hospital, 8700 Wisconsin Ave., Milwaukee, Wisc. 53226. sidered a factor in the pathogenesis of these disorders $(1,4,5)$.

The role of metabolic acidosis has not been critically tested. Although Albright and Reifenstein considered acidosis the major cause of azotemic bone disease (4), other studies $(2,5,6)$ have failed to find calcium retention after alkali therapy. Such studies have often been brief, and alkali therapy has frequently been continued while other forms of therapy were evaluated.

We carried out the present studies to determine whether the continuous and complete correction of the acidosis of chronic renal disease had any significant influence on calcium balance.

\section{Methods}

Eight paired metabolic balance studies were carried out in seven patients with chronic azotemic renal disease during periods of spontaneous but stable acidosis and during periods when the serum bicarbonate concentration was maintained at stable normal levels by the continuous administration of sodium bicarbonate. None 
of the subjects' serum bicarbonate concentrations changed by more than $\pm 1 \mathrm{mEq}$ per $\mathrm{L}$ on the eight or more determinations during each of the separate parts of the paired studies. Each phase of the study of every patient consisted of three or four consecutive 6-day metabolic periods. All patients were hospitalized in the Clinical Research Center, Marquette University School of Medicine, and each patient ate a constant diet. Six of the studies were carried out first while the patient was acidotic and then repeated after at least 2 weeks of $\mathrm{NaHCO}_{3}$ therapy. Two studies were carried out in patients who had been receiving adequate $\mathrm{NaHCO}_{3}$ therapy for many months and were repeated several weeks after alkali therapy had been stopped. Table I presents the pertinent clinical data for each patient. All but one had radiographic evidence of slight diffuse demineralization of bone, and three had changes consistent with secondary hyperparathyroidism (subperiosteal bone resorption in phalanges). None had significant bacteriuria.

Each patient was allowed 3 to 6 days to adapt to his constant diet before balance observations were begun. The diets were typical of ordinary American diets and were adjusted to the patient's customary food intake. Duplicate daily diets were prepared and analyzed on eight to twelve occasions during each study. The average coefficient of variation for the analyses of each diet constituent was as follows: $\mathrm{Na}, \pm 4.1 \% ; \mathrm{K}, \pm 4.4 \%$; Ca, $\pm 4.2 \%$; $\mathrm{Mg}, \pm 4.3 \% ; \mathrm{Cl}, \pm 4.0 \%$; and $\mathrm{P}, \pm 4.7 \%$.

The constant daily doses of $\mathrm{NaHCO}_{3}$ required to maintain normal stable serum bicarbonate levels were weighed on an analytical balance and administered in gelatin capsules in four divided daily doses. Sodium bicarbonate doses of 61 to $180 \mathrm{mEq}$ per day were required to maintain normal serum bicarbonate levels because of the variable reduction in renal tubular reabsorptive threshold for bicarbonate in patients with renal disease (7). Each patient received one multivitamin capsule daily containing 1,000 USP U of vitamin D.

In five paired studies the patients were given $10.0 \mathrm{mEq}$ of stable strontium as the gluconate 1 intravenously at the beginning of a metabolic period while acidotic and again when the serum bicarbonate was kept at steady normal levels by $\mathrm{NaHCO}_{3}$ therapy. Strontium was measured in serum, urine, and fecal ash by atomic absorption spectrophotometry with lanthanum in the diluent to suppress anionic interference. We carried out all strontium analyses for both phases of the study of each patient simultaneously to minimize analytical variability. Strontium was administered with the intention of estimating calcium turnover in bone by the method described by Fraser, Harrison, and Ibbertson (8). The validity of the use of strontium as a tracer for bone calcium turnover has been documented by other investigators $(9,10)$ as well. The calculations used by Fraser and co-workers (8) depend upon the fact that normal subjects excrete most of an injected dose of strontium in the urine. In their studies, normal subjects excreted only 8 to $16 \%$ of a $10-\mathrm{mEq}$ intravenous dose of strontium in

1 Kindly supplied by Dr. C. D. Burrell, Sandoz Pharmaceuticals, Hanover, N. J.

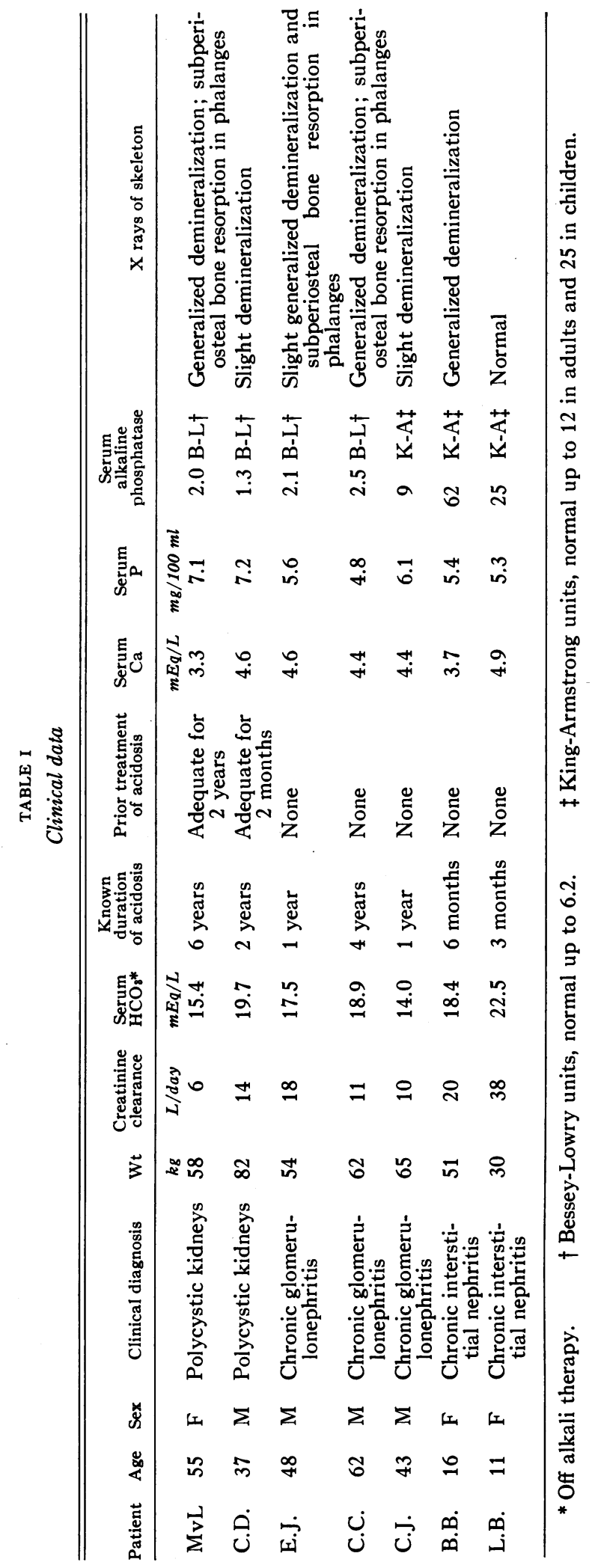


TABLE II

Average blood and serum measurements

\begin{tabular}{|c|c|c|c|c|c|}
\hline & & Acidosis & Alkali therapy & $\Delta^{*}$ & $\mathrm{p} \dagger$ \\
\hline \multicolumn{6}{|l|}{ Whole blood } \\
\hline $\mathrm{H}^{+}$ & $n E q / L$ & $\begin{array}{l}49.3 \pm 3.6 \\
(\mathrm{pH} 7.31)\end{array}$ & $\begin{array}{l}40.6 \pm 3.6 \\
(\mathrm{pH} 7.39)\end{array}$ & $-8.7 \pm 3.0$ & $<0.001$ \\
\hline \multicolumn{6}{|l|}{ Serum } \\
\hline $\begin{array}{l}\mathrm{HCO}_{3}^{-} \\
\mathrm{PCO}_{2} \ddagger \\
\mathrm{Na} \\
\mathrm{K} \\
\mathrm{Cl} \\
\text { Unmeasured anion } \S \\
\mathrm{Ca} \\
\mathrm{P} \\
\mathrm{Mg} \\
\text { Creatinine }\end{array}$ & $\begin{array}{l}m E q / L \\
m m H g \\
m E q / L \\
m E q / L \\
m E q / L \\
m E q / L \\
m E q / L \\
m g / 100 m l \\
m E q / L \\
m g / 100 m l\end{array}$ & $\begin{array}{c}18.7 \pm 3.2 \\
38 \pm 6 \\
139 \pm 3 \\
4.8 \pm 0.9 \\
108 \pm 3 \\
10 \pm 3 \\
4.4 \pm 0.6 \\
5.7 \pm 1.1 \\
2.1 \pm 0.2 \\
8.0 \pm 3.5\end{array}$ & $\begin{array}{c}27.4 \pm 2.1 \\
46 \pm 2 \\
140 \pm 2 \\
4.6 \pm 0.9 \\
98 \pm 6 \\
14 \pm 5 \\
4.4 \pm 0.9 \\
5.9 \pm 1.6 \\
2.1 \pm 0.2 \\
8.4 \pm 3.8\end{array}$ & $\begin{array}{l}+8.7 \pm 3.5 \\
+8 \pm 7 \\
+1 \pm 3 \\
-0.2 \pm 0.4 \\
-10 \pm 6 \\
+4 \pm 4 \\
00.4 \pm 0.4 \\
+0.2 \pm 1 \\
0 \pm 0.2 \\
+0.4 \pm 2.0\end{array}$ & $\begin{array}{l}<0.001 \\
<0.025 \\
\text { NS } \\
\text { NS } \\
<0.005 \\
<0.05 \\
\text { NS } \\
\text { NS } \\
\text { NS } \\
\text { NS }\end{array}$ \\
\hline
\end{tabular}

* $\Delta=$ Value during sodium bicarbonate therapy minus value during acidosis.

$\dagger$ Probability that the mean change is not different from zero.

$\ddagger \mathrm{CO}_{2}$ pressure.

$\S\left[\mathrm{Na}^{+}\right]-\left(\left[\mathrm{Cl}^{-}\right]+\left[\mathrm{HCO}_{3}^{-}\right]\right)$.

the feces during the first 6 days after injection, and this was neglected in their kinetic analyses. Studies in our laboratory of two normal subjects who were given 10 $\mathrm{mEq}$ of strontium intravenously showed that they excreted 33 and $38 \%$ of the dose in the urine in 6 days and 8 and $10 \%$ in the feces during the same period. By contrast, the patients with renal disease excreted, at most, $14 \%$ of the dose of strontium in the urine while excreting as much of the dose in the feces as did normal subjects. Thus, kinetic analyses of these data could not be carried out because strontium was excreted primarily in

TABLE III

Mean daily diet and stool composition

\begin{tabular}{llrl}
\hline & & Acidosis & Alkali therapy \\
\hline Diet & & & \\
$\mathrm{Na}$ & $m E q$ & $131 \pm 29^{*}$ & $68 \pm 10^{*}$ \\
$\mathrm{~K}$ & $m E q$ & $63 \pm 8$ & $67 \pm 10$ \\
$\mathrm{Ca}$ & $m E q$ & $27 \pm 14$ & $28 \pm 14$ \\
$\mathrm{Mg}$ & $m E q$ & $19 \pm 3$ & $20 \pm 3$ \\
$\mathrm{Cl}$ & $m E q$ & $130 \pm 30$ & $68 \pm 12$ \\
$\mathrm{P}$ & $m m o l e s$ & $31 \pm 7$ & $32 \pm 7$ \\
& & & \\
Stool & & & \\
$\mathrm{Weight}$ & $g$ & $92 \pm 47$ & $94 \pm 39$ \\
$\mathrm{Na}$ & $m E q$ & $2 \pm 2$ & $2 \pm 2$ \\
$\mathrm{~K}$ & $m E q$ & $10 \pm 4$ & $11 \pm 5$ \\
$\mathrm{Ca}$ & $m E q$ & $30 \pm 16$ & $28 \pm 15$ \\
$\mathrm{Mg}$ & $m E q$ & $14 \pm 4$ & $14 \pm 4$ \\
$\mathrm{Cl}$ & $m E q$ & $1 \pm 1$ & $1 \pm 1$ \\
$\mathrm{P}$ & $m m o l e s$ & $14 \pm 5$ & $14 \pm 6$ \\
& & & \\
\hline
\end{tabular}

* These values are the sodium content of the basic diets. During acidosis, an average of 6 additional $\mathrm{mEq}$ of sodium per day was fed as bicarbonate because two patients required small daily doses of bicarbonate to prevent symptomatic acidosis. During treatment an average of $107 \mathrm{mEq} \mathrm{NaHCO}_{3}$ was fed each day in addition to the basic diet. the feces, and the excretion into the gut on a given day of the study could not be determined accurately because of the variable lag between fecal formation and defecation. Nevertheless, it was possible to compare the amount of strontium retained in the body 6 days after injection and the corresponding serum strontium concentrations in the same subject before and after treatment of acidosis. Alkali therapy had no apparent effect on the frequency of defecation or the quantity of feces excreted per 6-day metabolic period. During those periods in which strontium was injected, average daily stool weight was $119 \pm 38 \mathrm{~g}$ during acidosis and $116 \pm$ $30 \mathrm{~g}$ during alkali therapy.

All other procedures, analytical methods, and calculations have been described in a previous publication (11). As in our earlier studies, carmine markers were used to delineate stool periods. All experimental results are presented as mean values $\pm 1 \mathrm{SD}$.

\section{Results}

The average concentrations of blood and serum constituents during stable acidosis and after bicarbonate therapy are presented in Table II. Alkali therapy significantly reduced blood $\left[\mathrm{H}^{+}\right]$ and raised serum $\left[\mathrm{HCO}_{3}^{-}\right]$. Compensatory reductions in $\mathrm{CO}_{2}$ pressure $\left(\mathrm{PCO}_{2}\right)$ and $\left[\mathrm{Cl}^{-}\right]$occurred. "Unmeasured anions" ${ }^{2}$ rose significantly, presumably because the anionic charges of the serum proteins increased. The remaining electrolyte concentrations and the serum creatinine concentrations did not change.

The mean values for the diet analyses are shown in the upper part of Table III. Sodium and

$$
{ }^{2}\left[\mathrm{Na}^{+}\right]-\left(\left[\mathrm{Cl}^{-}\right]+\left[\mathrm{HCO}_{3}^{-}\right]\right) \text {. }
$$


TABLE IV

Mean daily mineral balances and change in body weight

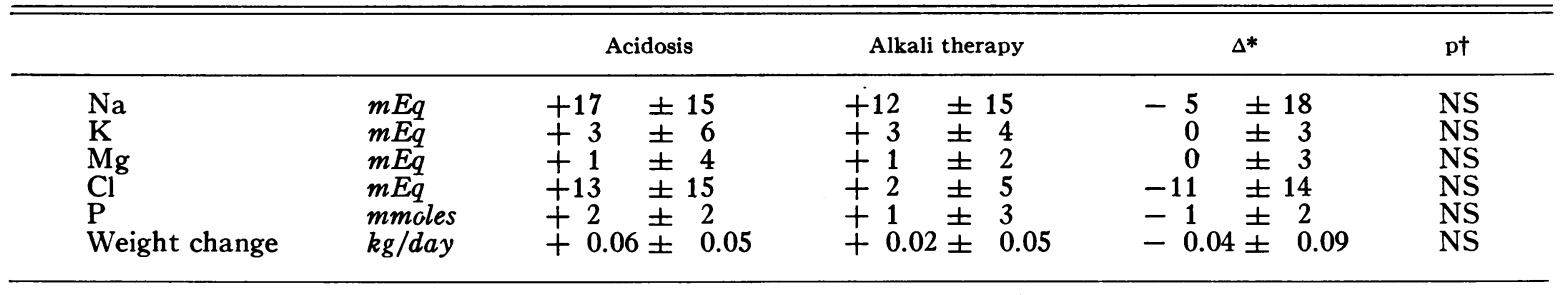

* Value during sodium bicarbonate therapy minus value during acidosis.

$\dagger$ Probability that the mean change is not different from zero.

chloride intakes differed in the two parts of each study because the quantity of $\mathrm{NaCl}$ added to the diets was reduced when $\mathrm{NaHCO}_{3}$ therapy was begun. The mean values for the remainder of the diet analyses were not different. The mean stool weight and fecal electrolyte contents are shown in the lower part of Table III. No significant changes occurred.

The average changes in body weight and the mean balances of $\mathrm{Na}, \mathrm{K}, \mathrm{Mg}, \mathrm{Cl}$, and $\mathrm{P}$ during acidosis and after alkali therapy are presented in Table IV. No significant changes were found.

The most pertinent findings in each of the paired studies are shown in Table V. The values given for each patient during acidosis and during alkali therapy are the means of all metabolic periods observed in that study. The first three columns show that mild to moderate acidosis was present in each patient before therapy, and that the serum $\left[\mathrm{HCO}_{3}^{-}\right]$was normal during $\mathrm{NaHCO}_{3}$ therapy. The mean change in serum $\left[\mathrm{HCO}_{3}^{-}\right]$ after alkali therapy was $+8.7 \pm 3.5 \mathrm{mEq}$ per $\mathrm{L}$ $(p<0.001)$. The effect of alkali therapy on calcium balance is shown in the next three columns. During acidosis, small negative calcium balances were observed in each study, averaging $-5.3 \pm$ $3.8 \mathrm{mEq}$ per day. This differed significantly from zero balance $(\mathrm{p}<0.01)$. With $\mathrm{NaHCO}_{3}$ therapy, calcium balance was less negative in six of the eight studies, and, for the group, was no longer significantly different from zero balance $(p>0.3)$. The mean change in calcium balance after alkali therapy was significant $(p=0.025)$. The urinary calcium excretion (not shown in the Table) was very low in both parts of each study, averaging $1.7 \pm 0.9 \mathrm{mEq}$ per day during acidosis and $1.5 \pm 0.9 \mathrm{mEq}$ per day during alkali therapy.

The next three columns of Table $\mathrm{V}$ give the per cent of a $10-\mathrm{mEq}$ intravenous dose of strontium retained 6 days after injection in each of five patients while acidotic and again after $\mathrm{NaHCO}_{3}$ therapy. Each patient retained more of the strontium after alkali therapy; despite this the serum concentration of strontium 6 days after administration (shown in the next three columns) was lower. The cumulative urinary strontium excretion (not shown in the Table) was low, averaging $9 \pm 5 \%$ of the dose during acidosis and $6 \pm 3 \%$ during alkali therapy. Most of the strontium appeared in the feces $(18 \pm 6 \%$ of the dose during acidosis and $12 \pm 3 \%$ when the serum bicarbonate was normal).

The final three columns of Table $\mathrm{V}$ show the apparent net external acid balances, calculated as described previously (11). The mean acid balance in each phase of the studies was not significantly different from zero, but the change in acid balance between the paired studies was significant $(p<0.01)$. In seven of the eight studies acid balance was less positive during alkali therapy.

The parameters of acid balance for the group are presented in Table VI. During alkali therapy, the sum of urinary $\mathrm{SO}_{4}=$ and organic acid salts increased significantly, due entirely to an increase in the amount of total organic acids existing as anions in the more alkaline urines. The calculated dietary and stool combustible anions were unchanged. Net fixed acid production, including the $\mathrm{NaHCO}_{3}$ administered, was significantly reduced. Renal acid excretion also fell significantly as a result of losses of bicarbonate in the urine during alkali therapy. However, the reduction in acid excretion during alkali therapy was not so great as the reduction in acid production, and thus the acid balance was significantly less positive. 


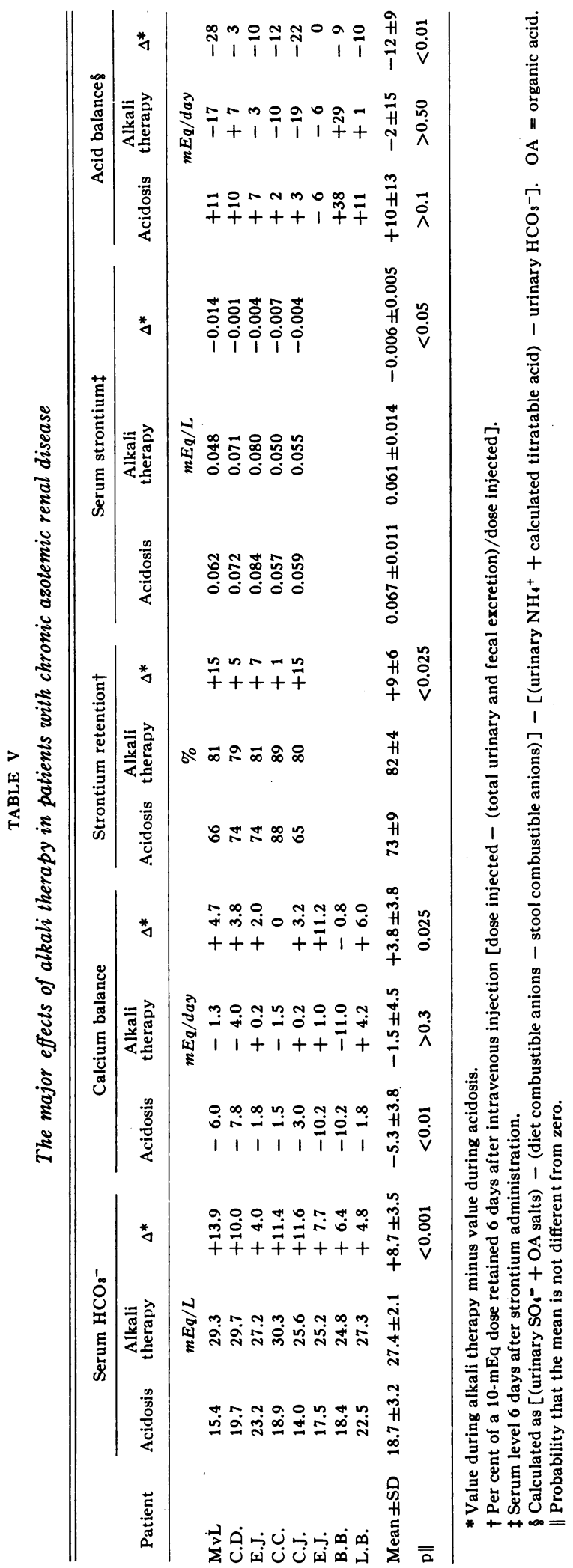

\section{Discussion}

A negative calcium balance was found in each patient with chronic azotemic renal disease when stable metabolic acidosis was present. As in other studies of calcium metabolism in azotemic subjects, the patients excreted only very small quantities of calcium in the urine (12), but fecal calcium content equaled or exceeded dietary calcium intake $(2,5,6)$. The daily losses of calcium were small, averaging $-5.3 \pm 3.8 \mathrm{mEq}$, but statistically different from zero balance $(p<0.01)$. It is likely that such losses are also physiologically significant when the potential duration of azotemic acidosis is considered. Projected over 10 years, the daily loss of $5 \mathrm{mEq}$ of calcium would expend nearly one-third of the total calcium contained in the skeleton of an average adult.

When the acidosis was completely corrected by continuous sodium bicarbonate therapy, calcium losses from the body were significantly reduced, although no detectable change in total serum calcium concentration was found. In addition, increased retention of intravenously administered strontium occurred despite lower serum strontium levels.

These results suggest that the correction of metabolic acidosis accelerated the rate at which calcium and strontium left the extracellular fluid and entered some other tissue, presumably bone. With alkali therapy, the rates at which calcium entered and left bone apparently became equal, since external calcium balance was restored to zero.

These studies, while indicating that alkali therapy alone can prevent continuing losses of calcium in chronic azotemic acidosis, confirm the findings of others $(2,5,6)$ that such therapy fails to induce absolute calcium retention. Many investigators $(2,5,6)$ have observed far more impressive calcium retention in patients with renal disease treated with pharmacologic doses of vitamin $\mathrm{D}$, and a state of acquired vitamin $\mathrm{D}$ resistance is now generally accepted as a feature of chronic azotemia. However, a similar failure to repair induced calcium deficits has been found in normal subjects recovering from experimental $\mathrm{NH}_{4} \mathrm{Cl}$ acidosis $(13,14)$. It is thus conceivable that normal homeostatic responses evoked by the correction of metabolic acidosis might in some way delay 
TABLE VI

The parameters of the acid balance

\begin{tabular}{|c|c|c|c|c|}
\hline & Acidosis & Alkali therapy & $\Delta \dagger$ & $\mathrm{p} \ddagger$ \\
\hline & & $m E q / d a y$ & & \\
\hline $\begin{array}{l}\text { Urinary } \mathrm{SO}_{4}^{-}+\mathrm{OA} \text { salts } \\
\text { Diet combustible anions* } \\
\text { Stool combustible anions* } \\
\mathrm{NaHCO}_{3} \text { fed } \\
\text { Net fixed acid production } \\
\text { Renal acid excretion } \\
\text { Acid balance }\end{array}$ & $\begin{array}{r}61 \pm 13 \\
54 \pm 10 \\
29 \pm 8 \\
6 \\
+30 \pm 20 \\
20 \pm 11 \\
+10 \pm 13\end{array}$ & $\begin{array}{r}67 \pm 11 \\
56 \pm 12 \\
28 \pm 6 \\
107 \\
-68 \pm 40 \\
-66 \pm 32 \\
-2 \pm 15\end{array}$ & $\begin{array}{l}+6 \pm 6 \\
+2 \pm 7 \\
-1 \pm 4 \\
+101 \pm \\
-98 \pm 34 \\
-86 \pm 30 \\
-12 \pm 9\end{array}$ & $\begin{array}{l}<0.05 \\
\text { NS } \\
\text { NS } \\
<0.001 \\
<0.001 \\
<0.01\end{array}$ \\
\hline
\end{tabular}

* $\left(\mathrm{Na}^{+}+\mathrm{K}^{+}+\mathrm{Ca}^{++}+\mathrm{Mg}^{++}\right)-\left(\mathrm{Cl}^{-}+1.8\right.$ mmoles $\left.\mathrm{P}\right)$.

$\dagger \Delta=$ values during sodium bicarbonate therapy minus values during acidosis.

$\ddagger$ Probability that the mean change is not different from zero.

skeletal remineralization. As Heaney has recently stressed (15), the hormonal control of calcium metabolism in the adult appears to defend primarily the ionized calcium concentration of body fluids. When metabolic acidosis is treated with alkali, both redeposition of calcium in bone and an increased affinity of plasma proteins for calcium would tend to lower the serum ionized calcium concentration. This change would presumably be opposed by increased parathyroid hormone secretion, with a resultant increase in intestinal and renal tubular calcium reabsorption, but also an increased mobilization of calcium from bone. The effect of parathyroid hormone on bone itself, although aiding in the stabilization of the blood ionized calcium concentration, would paradoxically retard the repair of skeletal calcium deficits. By contrast, the primary action of pharmacologic doses of vitamin $\mathrm{D}(2,5,6)$ or massive oral administration of calcium salts (16) would be to increase intestinal calcium absorption. In this circumstance, serum ionized calcium would tend to rise, parathyroid hormone secretion would decrease, and deposition of calcium in bone would be favored.

Regardless of the intimate mechanisms, the results of the present studies are consistent with a previous suggestion (17) that slow losses of calcium from the skeleton might occur in chronic azotemic renal disease while acidosis was present, but not when the acidosis was adequately treated. As in earlier investigations $(17,18)$, an apparent continuing retention of acid was found during periods when the serum $\left[\mathrm{HCO}_{3}^{-}\right]$was reduced but stable. If it is assumed that the actual acid balance was zero during alkali therapy (18), the apparent acid retention during acidosis averaged $12 \pm 9$
$\mathrm{mEq}$ per day. The simultaneous losses of calcium, regardless of the salts from which they arose, could not account for the retention of this quantity of acid. It is most likely that this quantitative discrepancy resulted from difficulties inherent in calculating acid production when whole food diets were used (11). An alternative possibility is that the valence of phosphorus in the feces increased significantly during acidosis in these azotemic patients, and fecal losses of combustible anions were thus overestimated.

\section{References}

1. Kaye, M., J. E. Pritchard, G. W. Halpenny, and W. Light. Bone disease in chronic renal failure with particular reference to osteosclerosis. Medicine (Baltimore) 1960, 39, 157.

2. Stanbury, S. W., and G. A. Lumb. Metabolic studies of renal osteodystrophy. I. Calcium, phosphorus and nitrogen metabolism in rickets, osteomalacia and hyperparathyroidism complicating chronic uremia and in the osteomalacia of the adult Fanconi syndrome. Medicine (Baltimore) 1962, 41, 1.

3. Pellegrino, E. D., and R. M. Blitz. The composition of human bone in uremia. Observations on the reservoir functions of bone and demonstration of a labile fraction of bone carbonate. Medicine (Baltimore) $1965,44,397$.

4. Albright, F., and E. L. Reifenstein, Jr. The Parathyroid Glands and Metabolic Bone Disease. Baltimore, Williams \& Wilkins, 1948, p. 116.

5. Liu, S. H., and H. I. Chu. Studies of calcium and phosphorus metabolism with special reference to pathogenesis and effects of dihydrotachysterol (A.T.10) and iron. Medicine (Baltimore) 1943, 22, 103.

6. Dent, C. E., C. M. Harper, and G. R. Philpot. The treatment of renal-glomerular osteodystrophy. Quart. J. Med. 1961, 30, 1. 
7. Schwartz, W. B., P. W. Hall, III, R. M. Hays, and A. S. Relman. On the mechanism of acidosis in chronic renal disease. J. clin. Invest. 1959, 38, 39.

8. Fraser, R., M. Harrison, and K. Ibbertson. The rate of calcium turnover in bone. Measurement by a tracer test using stable strontium. Quart. J. Med. 1960, 29, 85.

9. Dow, E. C., and J. B. Stanbury. Strontium and calcium metabolism in metabolic bone diseases. J. clin. Invest. 1960, 39, 885 .

10. Eisenberg, E., and G. S. Gordan. Skeletal dynamics in man measured by nonradioactive strontium. J. clin. Invest. 1961, 40, 1809.

11. Lennon, E. J., J. Lemann, Jr., and J. R. Litzow. The effects of diet and stool composition on the net external acid balance of normal subjects. J. clin. Invest. 1966, 45, 1601.

12. Lichtwitz, A., S. de Sèze, R. Parlier, D. Hioco, and P. Bordier. L'hypocalciurie glomérulaire. Bull. Soc. méd. Hôp. Paris 1960, 76, 98.

13. Farquharson, R. F., W. T. Salter, D. M. Tibbetts, and J. C. Aub. Studies of calcium and phosphorus metabolism. XII. The effect of the ingestion of acid-producing substances. J. clin. Invest. 1931, 10, 221.

14. Lemann, J., Jr., J. R. Litzow, and E. J. Lennon. The effects of chronic acid loads in normal man: further evidence for the participation of bone mineral in the defense against chronic metabolic acidosis. J. clin. Invest. 1966, 45, 1608.

15. Heaney, R. P. A unified concept of osteoporosis. Amer. J. Med. 1965, 39, 877.

16. McDonald, S. J., E. M. Clarkson, and H. E. de Wardener. The effect of a large intake of calcium citrate in normal subjects and patients with chronic renal failure. Clin. Sci. 1964, 26, 27.

17. Goodman, A. D., J. Lemann, Jr., E. J. Lennon, and A. S. Relman. Production, excretion, and net balance of fixed acid in patients with renal acidosis. J. clin. Invest. 1965, 44, 495.

18. Lemann, J., Jr., E. J. Lennon, A. D. Goodman, J. R. Litzow, and A. S. Relman. The net balance of acid in subjects given large loads of acid or alkali. J. clin. Invest. 1965, 44, 507. 